\title{
An Optimum Wind Solar Hybrid System for Stand -Alone Power Generation
}

\author{
W.D.A.S. Wijayapala and H.P. Hemantha Kumara
}

\begin{abstract}
The dynamic behaviour and simulation results of a stand - alone hybrid power generation system comprising of a wind turbine, solar array and battery storage are presented in this Paper. The objective of this study is to review the state of the simulation, optimization and control technologies of the stand-alone hybrid solar-wind energy system with the inclusion of battery storage.
\end{abstract}

The hybrid system used for the simulation consisted of a 100W wind turbine, 150W solar array and a 70Ah lead acid battery. A Fuzzy Logic Maximum Power Point Tracker (MPPT) controller was applied to the variable-speed, fixed-pitch small scale wind turbine while maximum power point tracking (MPPT) method based on Perturb \& Observation (P\&O) searching algorithm was applied to the stand-alone solar photovoltaic system.

MATLAB Simulink ${ }^{\mathrm{TM}} 7.2$ / Simpower system software environment was utilized to accomplish and simulate individual wind and PV dynamic models of the hybrid system. The public domain software, Hybrid Optimization Model for Electric Renewables (HOMER) produced by the National Renewable Energy Laboratory was used to optimize the hybrid system with data taken from a feasibility study together with meteorological data obtained from a selected area in Sri Lanka.

Keywords: Wind turbine, Photo voltaic, Lead acid battery, Hybrid system, Fuzzy logic

\section{Introduction}

Solar power and wind power are extensively utilized throughout the world specially for powering rural economies [1].

Photovoltaic technology has become a relatively cost effective method for rural areas where the main grid is not available. The variation of the intensity of solar energy falling on earth's surface with time and the impacts of the environmental conditions are challenges faced in obtaining a continuous electricity supply from the system. The generation of electricity from wind energy is also facing similar challenges due to diurnal and annual wind speed variations.

As a remedy for this problem, in this study, a photovoltaic system combined with a wind generation system is suggested to reduce zero- power intervals. Sunny days are usually quiet and not windy. However it is usually windy on cloudy days and at night. Therefore a solar/wind hybrid power system (HPS) will minimize the impacts of intermittency associated with these sources.

In this analysis, it is suggested to develop separate dynamic models for wind and photovoltaic systems with a storage battery system.
The operating point at which maximum power can be supplied to the load is called the Maximum Power Point (MPP). It is the single best point and the path to this point has a nonlinear variation with solar irradiation and cell temperature. For the tracking of MPP the Perturb \&Observation (P\&O) algorithm was used in this analysis.

For controlling the restoring torque of the generator for optimum operation of the wind turbine system, a Maximum Power Point Tracking (MPPT) control mechanism based on a fuzzy logic searching method for small wind turbine system was used.

MATLAB Simulink 7.2 / Simpower system software environment was used to carry out the simulation of individual wind and PV dynamic models of the hybrid system and HOMER software was used in optimizing the hybrid system.

Eng. W D A S Wijayapala, BSc Eng(Hons), MEng, Int PEng(SL), FIE(SL), CEng, MIEEE, Senior Lecturer, Department of Electrical Engineering, University of Moratuwa

HP Hemantha Kumara, MSc, AMIE (Sri Lanka), Senior Research Engineer, National Engineering Research and Development Centre 


\section{Small Scale Wind Turbine}

Small scale wind turbines generally operate in a variable speed variable frequency (VSVF)and constant pitch angle mode withyaw regulation to suit wind direction, and a tail rudder aligning the rotor against the wind. A passive controlling mechanism allows the rotor body to furl away in case of high winds against the rotor. These mechanisms are essential to regulate the power extracted by the system and to reduce structural stresses on the machine parts and the tower [2].

\section{Wind Turbine Model}

Variable speed wind turbines are usually characterized as having higher efficiency than fixed-speed wind turbines and hence are becoming more and more popular especially as small wind turbines. Normally, variable speed wind turbines are aerodynamically controlled, usually by using power electronics, to regulate the torque and the speed of the turbine to maximize the power output. Variable pitch aerodynamically controlled wind turbines are more costly and complex. Therefore, the variable-speed fixed pitch approach is becoming more popular for low cost constructions and has become the most common scheme for small wind turbines.

\subsection{Control Strategies}

The maximum power point tracking control mechanism is used to control the restoring torque of the generator for optimum operation of the wind turbine system [2]. The performance of variable speed fixed pitch wind turbines could be optimized without the need for a complex aerodynamic control. These turbines are usually operated in a way that the relevant optimum points of the wind rotor curve coincide, as shown in Figure1. Therefore, in order to obtain maximum output power from the turbine, it is necessary to drive it at an optimal rotor speed for a particular wind speed.

Wind speed, turbine rotational speed and turbine rotor characteristics are the main factors that determine the maximum power point. The generator characteristics may be used in order to control the restoring torque to track the optimum operating points. If the wind speed is varied from $V_{1}$ to $V_{4}$, the rotor speed should be changed from $\omega_{1}$ to $\omega_{4}$ for optimum operation of the wind turbine. However, the rotational speed of the wind turbine cannot be changed instantaneously. Usually, a controller in conjunction with an anemometer is used to control the wind turbine. In systems that employ an anemometer, the anemometer provides the reference signal to the MPPT controller. This reference is compared with the power extracted from the wind energy converter. In the absence of an anemometer in the control system, it is essential to estimate the wind speed. In such situations the generator output frequency and power or torque mapping techniques are used to track the MPP. Another way for MPP tracking is the use of 'searching' method, which is a suitable strategy for small wind turbines [3]. The output power is used as the feedback signal for the perturbation \& observation (hill climbed) algorithm, which is used to find the maximum power point of the system.

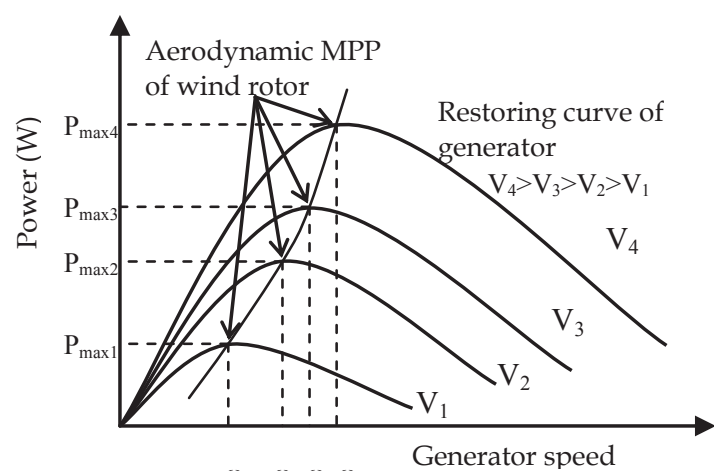

$\omega_{1} \omega_{2} \omega_{3} \omega_{4}$

Figure 1 - Output Power of Turbine versus Rotor Angular Speed

\subsection{Aerodynamic Characteristic of the Rotor}

Based on the wind turbine rotor aerodynamic behaviour, the turbine extracts only a part of the kinetic energy contained in the wind as given in Equation 1[4]

$$
P_{a}=\frac{1}{2} \rho \pi R^{2} v^{3} C_{p}
$$

Where $P_{a}$ is the captured power by the rotor, $R$ is the radius of the rotor, $\rho$ is the air density and $v$ is the speed of the incident wind. The proportion of the useful power is defined by the power coefficient $C_{p}$, which for a NACA 4415 aerodynamic profile wind rotor depends on the pitch angle of the rotor blades and on the tip speed ratio $(\lambda)$ defined as in Equation 2.

$$
\lambda=\frac{\omega \cdot R}{V}
$$

Where $\omega$ is the rotational speed

The rotor aerodynamic characteristics are represented by the $C_{p}-\lambda$ relationship. $C_{p}$ has a maximum value for an optimal tip speed ratio 
value $\left(\lambda_{\mathrm{opt}}\right)$. Near the optimum tip speed ratio, the power extraction is maximum for any given wind speed that results in the maximum power coefficient. For variable speed wind turbines, when wind speed varies, the rotor speed should be adjusted proportionally to maintain optimum tip speed ratio for maximum power extraction. Using Equation (1) aerodynamic torque $\left(\mathrm{T}_{\mathrm{a}}\right)$ by a wind rotor can be calculated as follows:

$T_{a}=\frac{1}{2} \rho \pi R^{3} v^{3} \frac{C_{p}}{\lambda}$

$T_{a}=\frac{1}{2} \rho \pi R^{3} v^{3} C_{T}$

Where $\mathrm{C}_{\mathrm{T}}$ is the torque coefficient and $\mathrm{T}_{\mathrm{a}}$ is the aerodynamic torque of the rotor.

The $C_{p} \& C_{T}-\lambda$ relationship of the wind turbine is shown in Figure 2.

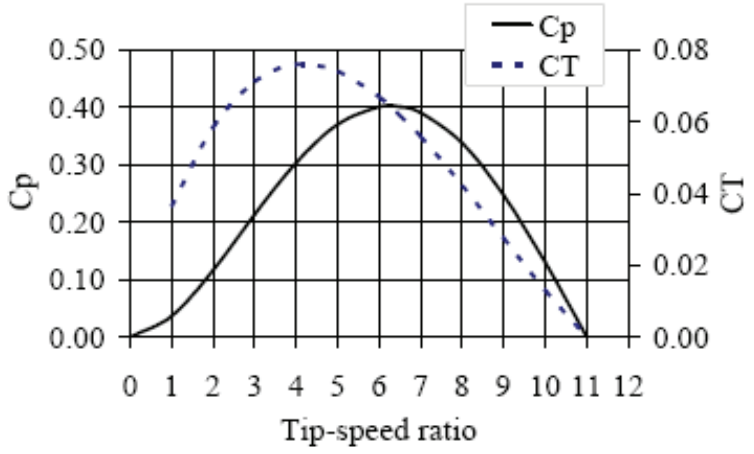

Figure 2 - Wind Rotor Characteristics

The aerodynamic torque of a wind turbine is a function of the wind speed (v) and the rotational speed $(\omega)$ of the rotor. For wind turbine-generator systems with a gearbox, the mechanical torque (the torque supplied to the generator) can be expressed by the relation,

$$
T=K . f(v . \omega)
$$

Where $K$ is the gear ratio. In small scale wind turbines, the rotor is directly coupled with the generator without a gearbox.

\section{Permanent Magnet Generator}

Small scale variable speed wind turbines are generally connected with a Permanent Magnet Generator (PMG) [3]. However DC motors are usually preferable due to their reliability, durability, low cost, voltage characteristics, positive convention coefficients between electrical and mechanical parts, sizing and design flexibility.
A permanent magnet DC motor converts electrical power provided by a voltage source to mechanical power by a rotor when there is a magnetic field. The equivalent circuit of a PMG is illustrated in Figure 3. The armature coil of the DC motor can be represented by an inductance $\left(\mathrm{L}_{\mathrm{m}}\right)$ in series with a resistance $\left(\mathrm{R}_{\mathrm{m}}\right)$ in series with induced voltage $\left(e_{m}\right)$ which opposes the voltage source. A differential equation for the equivalent circuit can be derived by using Kirchhoff's voltage law around the electrical loop.

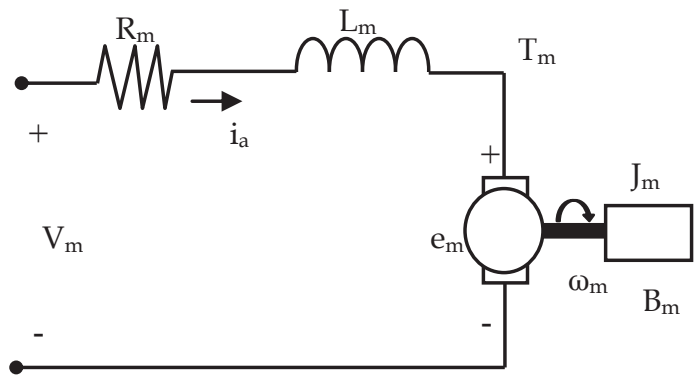

Figure 3 - Equivalent Circuit of a DC motor

The differential equations for the armature current and angular velocity in a state space form can be written as,

$\frac{d}{d t}\left[\frac{i_{a}}{\omega_{m}}\right]=\left[\begin{array}{cc}-\frac{R_{m}}{L_{m}} & \frac{K}{L_{m}} \\ \frac{K_{t}}{J} & -\frac{B}{J}\end{array}\right]\left[\begin{array}{c}i_{a} \\ \omega_{m}\end{array}\right]+\left[\begin{array}{cc}\frac{1}{L_{m}} & 0 \\ 0 & -\frac{1}{J}\end{array}\right]\left[\begin{array}{l}\frac{V_{m}}{T_{1}}\end{array}\right]$

The load torque is given by,

$$
T_{L}=K_{o}+K_{1} \omega_{m}+K_{2} \omega_{m}{ }^{2}
$$

The inertia (J) and viscous friction (B) have the following non-liner forms:

$$
\begin{aligned}
& B_{m}=B_{o}+B_{1} \omega_{m}+B_{2} \omega_{m}{ }^{2} \\
& J_{m}=J_{o}+J_{1} \omega_{m}+J_{2} \omega_{m}{ }^{2}
\end{aligned}
$$

\subsection{Restoring Torque of the Generator}

The restoring torque of a generator can be derived from the electromagnetic torque developed by the rotor shaft of the generator. The generator torque (which is defined as a negative motor torque) is a function of the generator current $\left(\mathrm{I}_{\mathrm{G}}\right)$, magnetic flux linkage and the number of pole pairs [5]. For a particular generator, magnetic flux linkage and the number of pole pairs are fixed parameters. Therefore, the restoring torque of a generator $\left(\mathrm{T}_{\mathrm{e}}\right)$ can be varied by controlling the current. 


\section{Maximum Power Point Tracking Control Mechanism}

The input mechanical power curve of the electric generator could be adjusted with the maximum power point of the rotor curves by varying the effective electric load on the generator. The system output power is interlaced with the wind turbine aerodynamic power and the rate of change of the mechanically stored energy. As the efficiency of the electric generator is variable, searching method estimation of the aerodynamic power from the electric output of the wind turbine system is difficult for maximum power point tracking.

$T_{a}=J \cdot \dot{\omega}+T_{e}$

Then,

$P_{a}=J \cdot \dot{\omega} . \omega+\frac{P_{e}}{\eta}$

$\left(\operatorname{asP}_{\mathrm{e}}=\eta \cdot \mathrm{T}_{\mathrm{e}} \cdot \omega\right)$

where $\mathrm{J}$ is the moment of inertia of the rotating parts, $\eta$ is the efficiency of the electric generator and $\mathrm{P}_{\mathrm{e}}$ is the power output of the generator [3].

The function of the maximum power point tracker is adapted by the load on the generator for the optimum operation of the system. A schematic diagram of the maximum power point tracker is shown in Figure 4.

By considering the Buck/Boost DC-DC converter voltage ratio,

$$
V_{B}=-V_{G}\left(\frac{D}{1-D}\right)
$$

and the corresponding current,

$$
I_{B}=-I_{G}\left(\frac{1-D}{D}\right)
$$

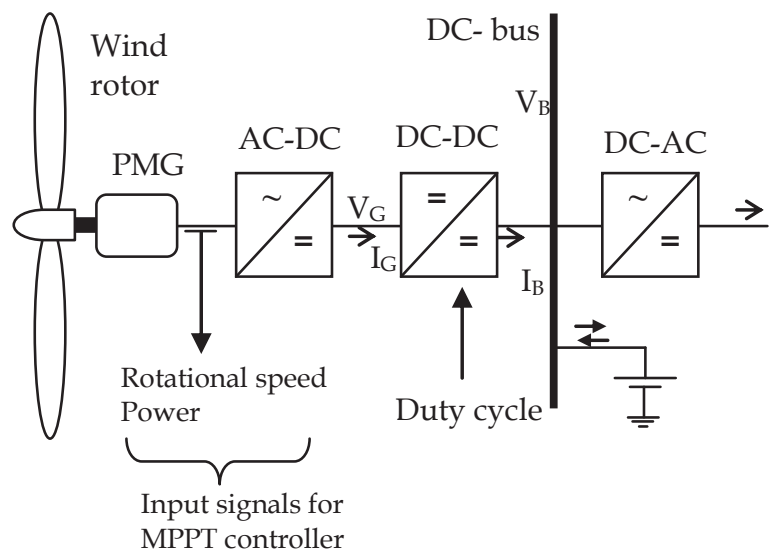

Figure 4 -Schematic of Small Scale Wind Power Generation System

$$
D=\left(\frac{T_{o n}}{T_{o n}+T_{\text {off }}}\right)
$$

$V_{B}$ is the voltage at the DC bus, $V_{G}$ is the voltage at the generator side, $\mathrm{I}_{\mathrm{B}}$ is the current flow towards the DC bus and $\mathrm{I}_{\mathrm{G}}$ is the current flow from the generator side in Figure 5.

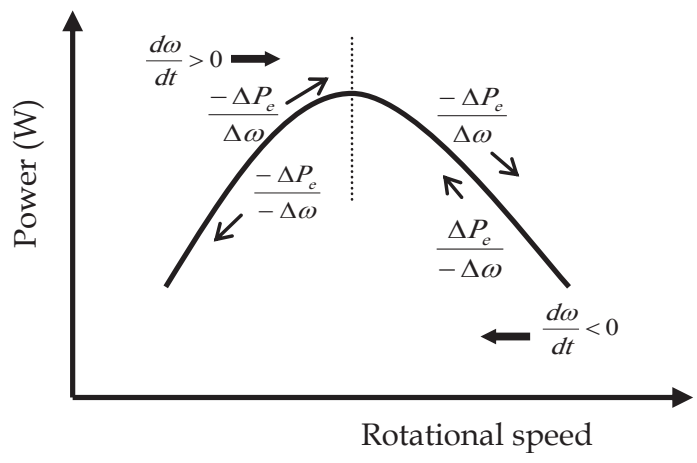

Figure 5 - Generator Restoring Torque Controlling Criteria

\section{Fuzzy Logic Controller}

Fuzzy logic is derived from the fuzzy set theory dealing with reasoning that is approximated (rather than precisely deduced) from classical predicted logic [6,7]. Fuzzy logic rules are used to control the restoring torque of the generator by considering $d p_{e} / d \omega$ and output $\Delta d$. The control criterion is demonstrated in Figure 5.The triangular shape membership functions are used to simplify the computational work. Related fuzzy sets and fuzzy rules are presented in Figure 6 and Table 1[8].

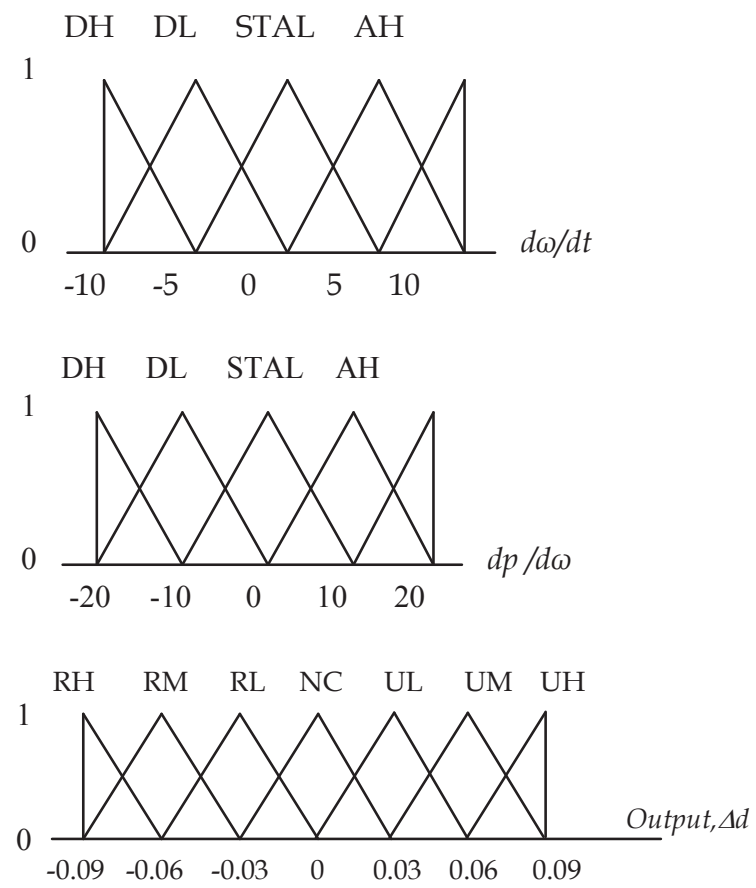

Figure 6 -Fuzzy Logic Input and Output Membership Functions 
Table 1 - Fuzzy Rules

\begin{tabular}{|c|c|c|c|c|c|}
\hline \multicolumn{2}{|c|}{ Input } & Output & \multicolumn{2}{|c|}{ Input } & Output \\
\hline$d \omega / d t$ & $d p / d \omega$ & $\Delta d$ & $d \omega / d t$ & $d p / d \omega$ & $\Delta d$ \\
\hline $\mathrm{DH}$ & $\mathrm{DH}$ & $\mathrm{NC}$ & $\mathrm{AL}$ & $\mathrm{ST}$ & $\mathrm{NC}$ \\
\hline $\mathrm{DL}$ & $\mathrm{DH}$ & UM & $\mathrm{AH}$ & ST & $\mathrm{NC}$ \\
\hline ST & $\mathrm{DH}$ & $\mathrm{NC}$ & $\mathrm{DH}$ & $\mathrm{AL}$ & RM \\
\hline $\mathrm{AL}$ & $\mathrm{DH}$ & UM & DL & $\mathrm{AL}$ & $\mathrm{RL}$ \\
\hline $\mathrm{AH}$ & $\mathrm{DH}$ & UH & ST & $\mathrm{AL}$ & $\mathrm{NC}$ \\
\hline $\mathrm{DH}$ & $\mathrm{DL}$ & UM & $\mathrm{AL}$ & $\mathrm{AL}$ & $\mathrm{NC}$ \\
\hline $\mathrm{DL}$ & $\mathrm{DL}$ & $\mathrm{NC}$ & $\mathrm{AH}$ & $\mathrm{AL}$ & RM \\
\hline ST & $\mathrm{DL}$ & $\mathrm{NC}$ & $\mathrm{DH}$ & $\mathrm{AH}$ & $\mathrm{RH}$ \\
\hline $\mathrm{AL}$ & $\mathrm{DL}$ & UL & DL & $\mathrm{AH}$ & RM \\
\hline $\mathrm{AH}$ & $\mathrm{DL}$ & UM & ST & $\mathrm{AH}$ & $\mathrm{NC}$ \\
\hline $\mathrm{DH}$ & ST & $\mathrm{NC}$ & $\mathrm{AL}$ & $\mathrm{AH}$ & $\mathrm{RM}$ \\
\hline $\mathrm{DL}$ & ST & $\mathrm{NC}$ & $\mathrm{AH}$ & $\mathrm{AH}$ & $\mathrm{NC}$ \\
\hline ST & ST & $\mathrm{NC}$ & & & \\
\hline
\end{tabular}

where DH:Decelerate High, RM:Reduce Medium, DL:Decelerate Low, RL:Reduce Low, ST:Steady, NC:Not Changed, AL:Accelerate Low, UL:Upgrade Low, AH:Accelerate High, UM:Upgrade Medium,RH:Reduce High, UH:Upgrade High.

\section{Photovoltaic Module}

\subsection{Simple PV Model}

The simple model of a PV cell is shown in Figure 7as an equivalent circuit that consists of an ideal current source in parallel with an ideal diode. The current source represents the current generated by photons (often denoted as $I_{p h}$ or $I_{L}$ ), and its output is constant under constant temperature and constant incident radiation of light.

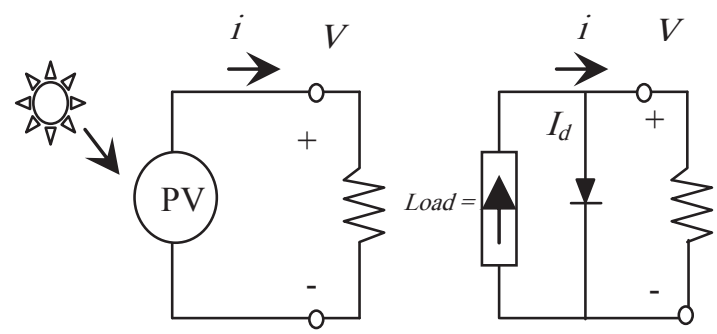

Figure 7 -PV Cell with a Load and a Simple Equitant Circuit

There are two key parameters commonly used to describe a PV cell. When the terminals of the PV cell are shorted together, as shown in Figure 8(a), the semiconductor generated current will flow out of the cell as a shortcircuit current $\left(\mathrm{I}_{\mathrm{sc}}\right)$. Thus, $\mathrm{I}_{\mathrm{ph}}=\mathrm{I}_{\mathrm{sc}}$. As shown in Figure $8(b)$, when there is no connection to the PV cell (open-circuit), the photon generated current is shunted internally by the fundamental p-n junction diode. This gives the open circuit voltage $\left(\mathrm{V}_{\text {oc }}\right)$. The PV panel or cell manufacturers usually give the values of these parameters in their datasheets.

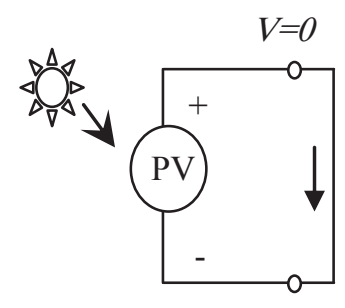

(a)

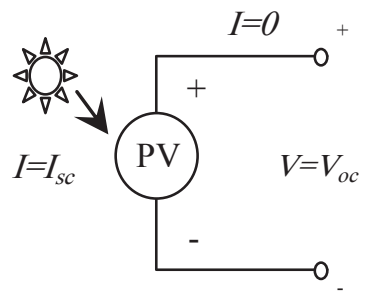

(b)
Figure 8 -PV Cell Short - Circuit and Open Circuit conditions

The output current (I) from the cell is calculated by applying the Kirchoff's current law on the equivalent circuit shown in Figure 7.

$$
I=I_{s c}-I_{d}
$$

$I_{s c}$ is the short-circuit current that is equal to the photon generated current, and $\mathrm{I}_{d}$ is the current shunted through the basic diode. The diode current $I_{d}$ is given by the Shockley's diode equation.

$$
I_{d}=I_{o}\left(e^{q V_{d} / K T}-1\right)
$$

$I_{0}$ is the reverse saturation current of diode (A), $\mathrm{q}$ is the electron charge $\left(1.602 \times 10^{-19} \mathrm{C}\right), \mathrm{V}_{\mathrm{d}}$ is the voltage across the diode $(\mathrm{V}), \mathrm{K}$ is the Boltzmann's constant $(1.381 \times 10-23 \mathrm{~J} / \mathrm{K})$ and $\mathrm{T}$ is the junction temperature in Kelvin (K).

Rearranging the equation by replacing $I_{d}$ of the Equation (15) by Equation (16) gives the current-voltage relationship of the PV cell as:

$I=I_{s c}-I_{o}\left(e^{q V / K T}-1\right)$

where $V$ is the voltage across the cell, and $I$ is the output current from the PV cell. The reverse saturation current of diode $\left(I_{0}\right)$ is constant at constant temperature and is found by setting the open-circuit condition as shown in Figure 8. Using Equation (17)with $\mathrm{I}=0$ (no output current):

$$
\begin{aligned}
& 0=I_{s c}-I_{o}\left(e^{q V_{o c} / K T}-1\right) \\
& I_{s c}=I_{o}\left(e^{q V_{o c} / K T}-1\right) \\
& I_{o}=\frac{I_{s c}}{\left(e^{q V_{o c} / K T}-1\right)}
\end{aligned}
$$

$\mathrm{I}_{\mathrm{sc}}$ is directly proportional to the level of irradiance, the intensity of illumination and to 
PV cell's properties[10]. Thus, if the value, $\mathrm{I}_{\mathrm{sc}}$, is known from the manufacturer's datasheet, under standard test conditions, $\mathrm{G}_{0}=1000 \mathrm{~W} / \mathrm{m}^{2}$ at air mass $(\mathrm{AM})=1.5$, the photon generated current at any other irradiance, $G\left(W / \mathrm{m}^{2}\right)$ will be given by

$$
\left.I_{s c}\right|_{G}=\left.\left(\frac{G}{G_{o}}\right) I_{s c}\right|_{G_{o}}
$$

Figure 9 shows the current and the voltage relationship (I-V curve) of an ideal PV cell simulated by MATLAB using the simple equivalent circuit model. The PV cell output is limited by the cell current and the cell voltage, and it can only generate power with any combinations of current and voltage on the I-V curve. It also shows that the cell current is proportional to the irradiance.

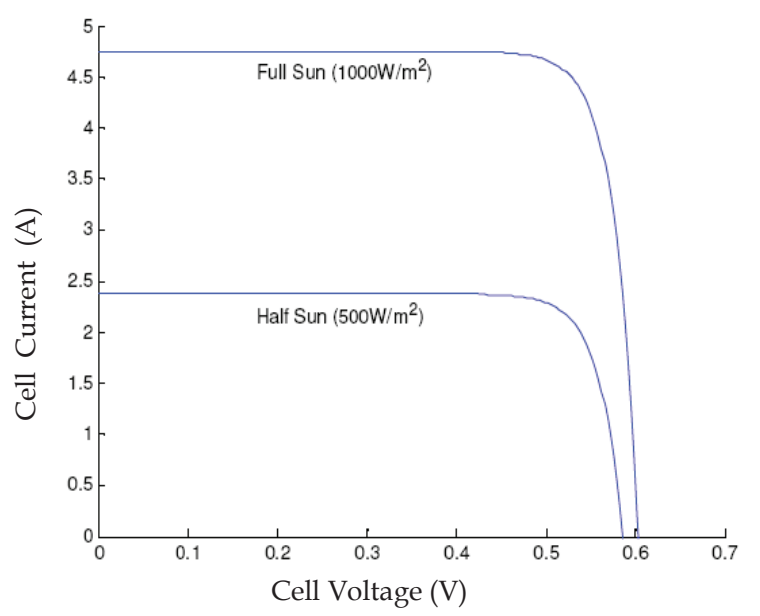

Figure 9 - I-Vplot of an ideal PV cell under two different irradiance levels at $25^{\circ} \mathrm{C}$

The more accurate PV model

There are some parameters that have not been taken into account in the simple photovoltaic model, which will affect the performance of a PV cell in its practical usage.

\section{a) Series Resistance}

In a practical PV cell, there is a series resistance $\left(R_{s}\right)$ added to the current path through the semiconductor material, the metal grid, contacts and current collecting bus.

\section{b) Parallel Resistance}

This is also called shunt resistance. It is a loss associated with the small leakage of current through a resistive path in parallel with the basic device. This can be represented by a parallel resister $\left(R_{p}\right)$. Its effect is much less obvious in a PV module compared to the series resistance, and it will only become evident when a number of PV modules are connected in parallel in a larger system.

\section{c) Recombination}

Recombination in the depletion region of PV cells provides non-ohmic current paths in parallel with the basic PV cell. As shown in Figure 10, this can be represented by a second diode (D2) in the equivalent circuit.

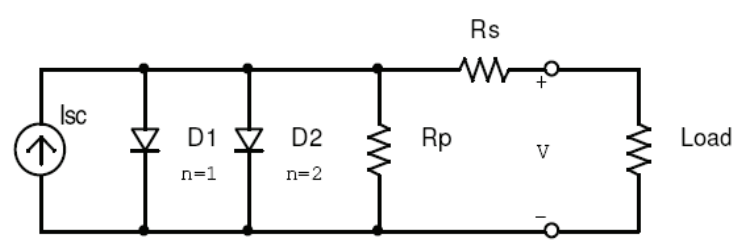

Figure 10 - More accurate equitant circuit of PV cell

$I=I_{s c}-I_{o 1}\left[e^{q\left(\frac{V+I . R_{s}}{K T}\right)}-1\right]-I_{o 2}\left[e^{q\left(\frac{V+I . R_{s}}{2 K T}\right)}-1\right]-\left(\frac{V+I \cdot R_{s}}{R_{p}}\right)$

It is possible to join the first diode $(D 1)$ and the second diode (D2) and rearrange the equation (22) in the following form:

$I=I_{s c}-I_{o}\left[e^{q\left(\frac{V+I . R_{s}}{n K T}\right)}-1\right]-\left(\frac{V+I . R_{s}}{R_{p}}\right)$

Since a single PV cell produces an output voltage less than $1 \mathrm{~V}$ (about $0.6 \mathrm{~V}$ for crystalline silicon cells), a number of PV cells are connected in series to achieve the desired output voltage. Most of the commercially available PV modules with crystalline-Si cells have either 36 or 72 series-connected cells. A 36-cell module provides a voltage suitable for charging a $12 \mathrm{~V}$ battery, and similarly a 72-cell module is appropriate for a $24 \mathrm{~V}$ battery. When the PV cells are connected together in series, the current output will be the same as the single cell, but the voltage output will be the sum of each cell voltage, as shown in Figure 11.

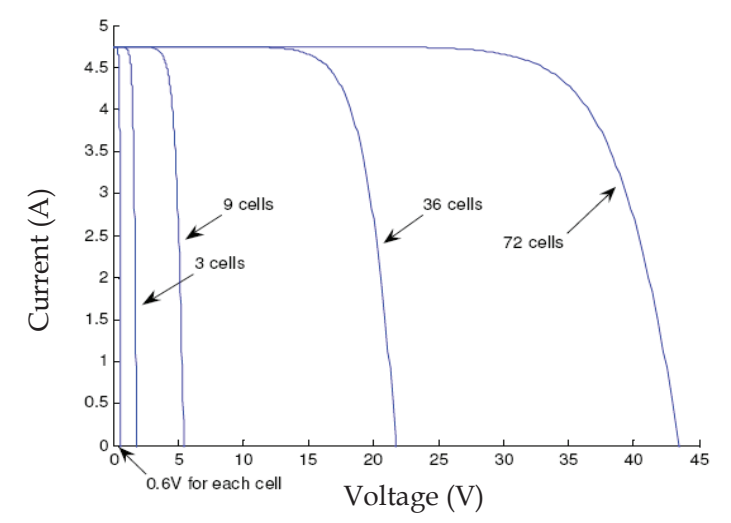

Figure 11 - PV Cells are connected in series to make up a PV Panel 
7.2 Modelling a PV module by MATLAB Solar BP SX 150S PV panel is chosen for the MATLAB simulation model. The module is made of 72 multi-crystalline silicon solar cells in series and provides 150W of nominal maximum power [11]. Table 2 shows its electrical specifications.

\section{Table 2 - Specifications of Solar BP SX 150S PV Panel}

\begin{tabular}{|l|l|}
\hline Maximum power $\left(P_{\max }\right)$ & $150 \mathrm{~W}$ \\
\hline Voltage at $P_{\max }\left(V_{\operatorname{mp}}\right)$ & $34.5 \mathrm{~V}$ \\
\hline Current at $P_{\max }\left(I_{m p}\right)$ & $4.35 \mathrm{~A}$ \\
\hline Open - circuit voltage $\left(V_{o c}\right)$ & $43.5 \mathrm{~V}$ \\
\hline Short - circuit current $\left(I_{s c}\right)$ & $4.75 \mathrm{~A}$ \\
\hline Temperature coefficient of $I_{s c}$ & $0.065 \pm 0.015 \% /{ }^{\circ} \mathrm{C}$ \\
\hline Temperature coefficient of $V_{o c}$ & $-160 \pm 20 \mathrm{mV} /{ }^{\circ} \mathrm{C}$ \\
\hline $\begin{array}{l}\text { Temperature coefficient of } \\
\text { power }\end{array}$ & $-0.5 \pm 0.05 \% /{ }^{\circ} \mathrm{C}$ \\
\hline
\end{tabular}

Modelling a PV module is not different from modelling a PV cell. It uses the same PV cell model. The parameters are the same, but only the voltage parameter (such as the open-circuit voltage) is different and has to be divided by the number of cells [12].

\section{Rs}

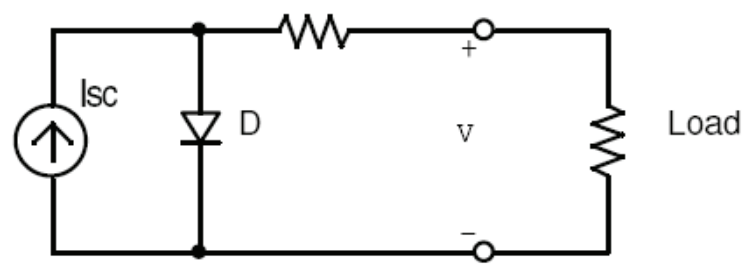

Figure 12 - Equitant Circuit used in the MATLAB Simulation

The model consists of a current source $\left(\mathrm{I}_{\mathrm{sc}}\right)$, a diode $(D)$, and a series resistance $\left(R_{s}\right)$. Since the effect of the parallel resistance $\left(R_{p}\right)$ is very small in a single module, it has not been included in the model. A better model, will also include temperature effects on the shortcircuit current $\left(\mathrm{I}_{\mathrm{sc}}\right)$ and the reverse saturation current of diode $\left(\mathrm{I}_{\mathrm{o}}\right)$. It uses a single diode with the diode ideality factor (n) set to achieve the best I-V curve match. Ideality factor, $\mathrm{n}$, takes the value between one and $\operatorname{two}(n=1$, for the ideal diode) [9]. The diode ideality factor (n) is unknown and must be predicted. After some trials with various diode ideality factors, the MATLAB model chose1.62 as the value for $n$ that attains the best match with the I-V curve on the datasheet and Figure 12 shows the effect of the varying the ideality factor.

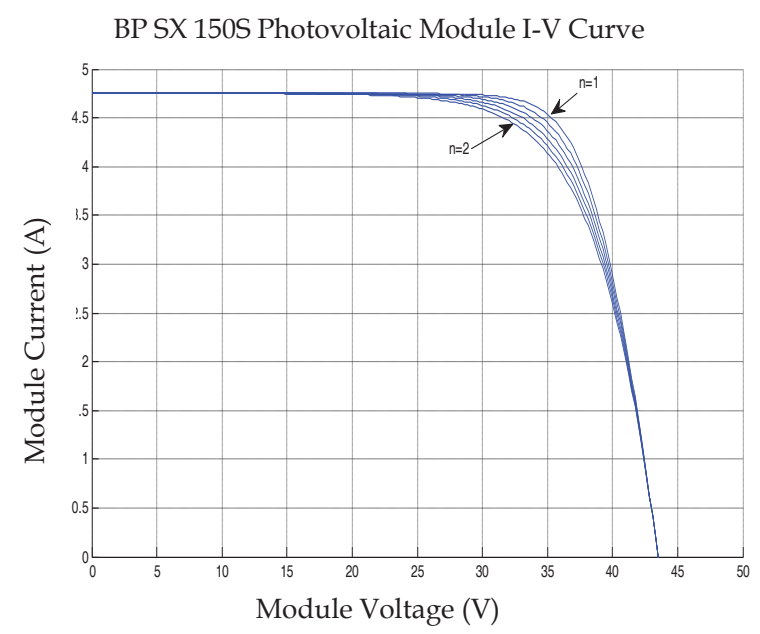

Figure 13 - Effect of diode ideality factor by MATLAB simulation at $1 \mathrm{~kW} / \mathrm{m}^{2}, 25^{\circ} \mathrm{C}$

Figure 14 shows the plots of I-V characteristics at various module temperatures simulated with the MATLAB model for BP SX 150S PV module. Data points placed over the plots are taken from the I-V curves on the manufacturer's datasheet [11].

BP SX 150S Photovoltaic Module I-V Curve

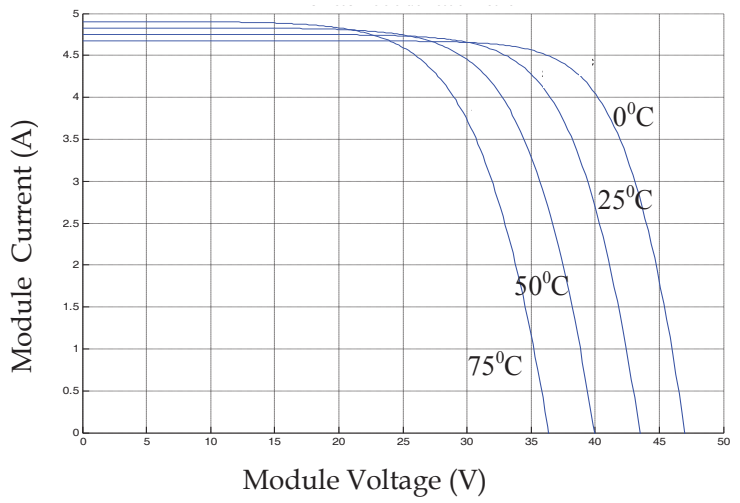

Figure 14 - I-V curve of PV module at various temperatures simulated with MATLAB $\left(1 \mathrm{~kW} / \mathrm{m}^{2}, 25^{\circ} \mathrm{C}\right)$

\section{Maximum Power Point Tracker (MPPT)}

A PV module can generate power at any operating point, anywhere on the I-V curve. There is a single point near the knee of the I-V curve, called the Maximum Power Point (MPP), at which the module operates with maximum efficiency and generates the maximum output power.

The MPPT has two problems to deal with. One is to find out the MPP for the prevailing solar irradiation level. The second is to track the MPPs as solar irradiation varies resulting in different peak power points [10]. 
The control system should operate the PV module at the MPP by managing loads and backup batteries [13].

\subsection{Maximum Power Point Tracking Algorithm}

The location of the MPP in the I-V plane is not known and all the time it will change dynamically depending on irradiance and temperature level on the PV panel. Figure 15 shows a set of PV I-V curves as irradiance is increased at constant temperature $\left(25^{\circ} \mathrm{C}\right)$, and Figure 16 shows the I-V curves at the same irradiance values but at a higher temperature $\left(50^{\circ} \mathrm{C}\right)$. As temperature changes the voltage at which the MPP shifts should be taken care of by the tracking algorithm of the MPPT [14].

The implementation of the open loop control method is simple although the MPPT efficiencies are relatively low. Since searching algorithm using a closed - loop control will produce higher efficiencies, it is usually selected for MPPT.

BP SX 150S Photovoltaic Module I-V Curve

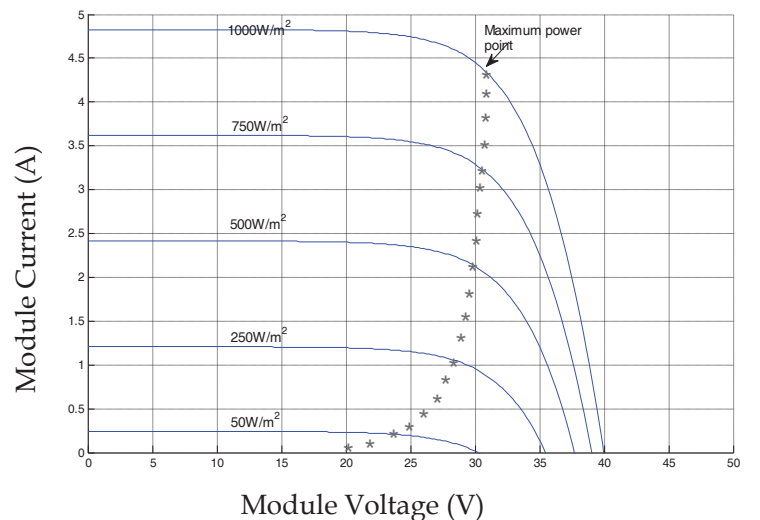

Figure 15 -I-V curves for varying irradiance and a trace of $\operatorname{MPPs}\left(25^{\circ} \mathrm{C}\right)$

BP SX 150S Photovoltaic Module I-V Curve

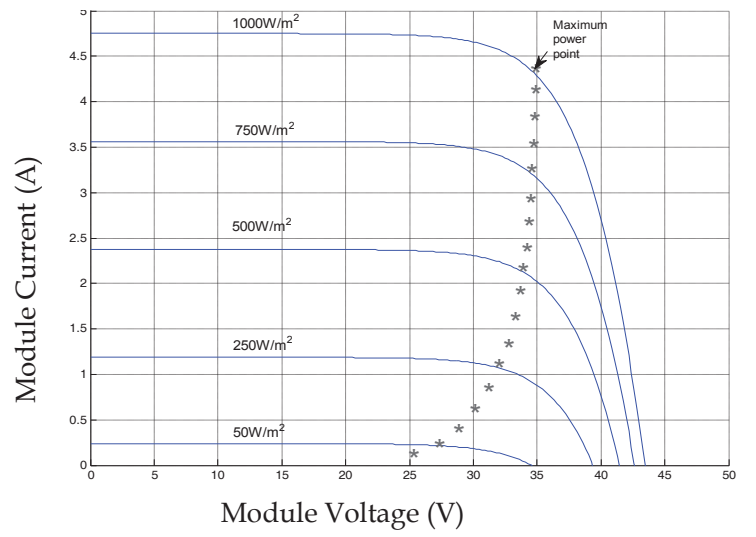

Figure 16 - I-V curve for varying irradiance and a trace of $\operatorname{MPPs}\left(50^{\circ} \mathrm{C}\right)$
8.2 Perturb \& Observe (P\&O) Algorithm In this study Perturb \&Observe (P\&O) algorithm, also identified as the "hill climbing" method is used. It is very popular and is the most frequently used algorithm in practice due to its simplicity and the ease of implementation. Figure 17 shows a PV module output power curve as a function of the voltage (P-V curve), at a constant irradiance and a constant module temperature, assuming that the PV module is operating at a point which is away from the corresponding MPP. In this algorithm the operating voltage of the PV module is perturbed by a small increment, and the resulting change of power, $\Delta P$, is observed. If the $\Delta P$ value is positive, then it is considered that it has moved the operating point closer to the MPP. Thus, further module voltage perturbations in the same direction should move the operating point towards the MPP. If the $\triangle P$ value is negative, the operating point has moved away from the MPP, and the direction of perturbation should be reversed to come back towards the MPP. Figure 17 shows the trace of MPPs on P-V curves at various irradiance levels and Figure 19 shows the flowchart of the $\mathrm{P} \& \mathrm{O}$ algorithm.

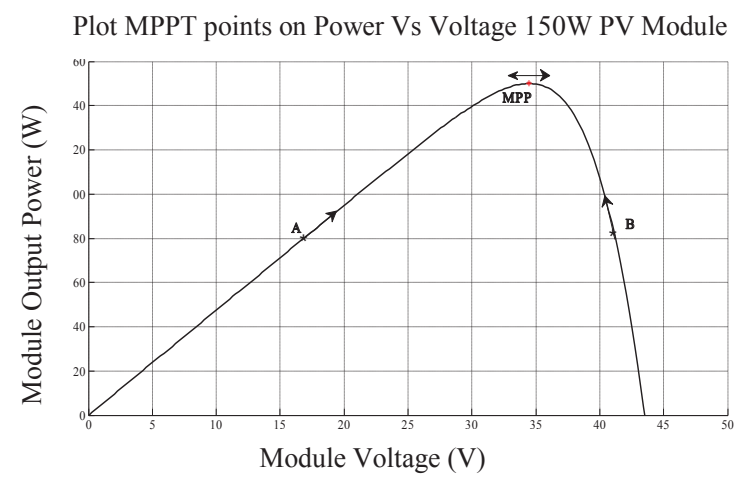

Figure 17 - Plot of power Vs voltage for PV module $\left(1 \mathrm{~kW} / \mathrm{m}^{2}, 25^{\circ} \mathrm{C}\right)$

Plot MPPT points on Power Vs Voltage 150W PV

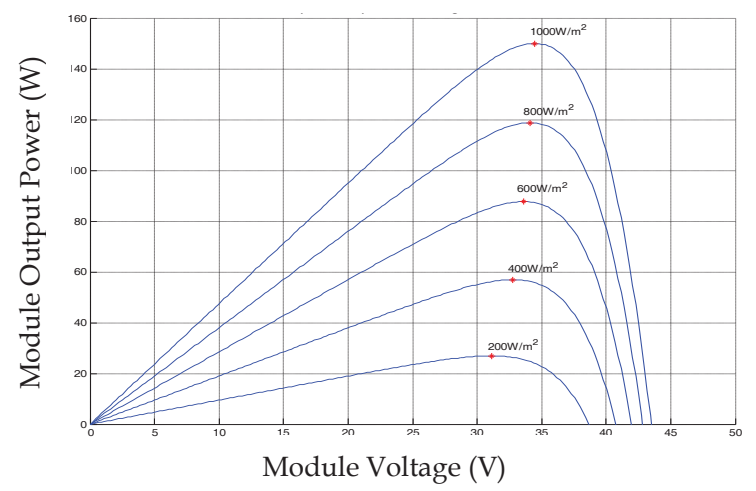

Figure 18 - MPP points on Power Vs Voltage curves at various irradiance levels 


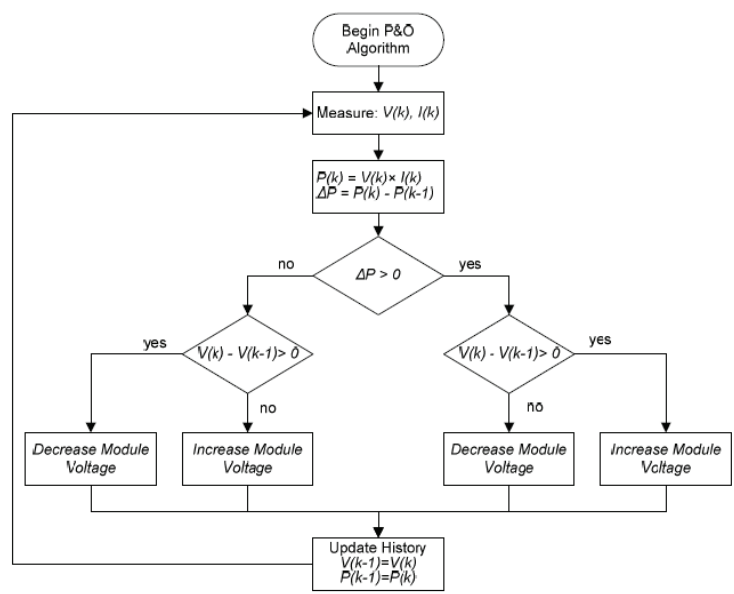

Figure 19 - Flowchart of the P \& O algorithm

\section{Modelling of the Battery Storage System}

Lead-acid batteries are commonly used in stand-alone wind solar hybrid power systems. A lead - acid battery is characterized by two indices. They are the battery State of Charge (SOC) and the floating voltage (or the terminal voltage) [15].

\subsection{Battery State of Charge Model}

The battery SOC determination gradually becomes more important in all of the applications that use a battery. The poor reliability of the SOC indication may induce undesirable situations, such as under charged, or overcharged.

The determination of the battery SOC may be a problem of some complexity depending on the battery type and on the application in which the battery is used. The most commonly used technique, the ampere hour counting method, is adopted for the SOC calculation.

For an exact knowledge of the real SOC of a battery, it is necessary to know the battery SOC at the starting point, the charge or discharge time and the current value [16]:

$$
S O C=S O C_{0}+\int_{t_{o}}^{t}\left(\frac{I_{b a t}}{C_{b a t}}\right) d \tau
$$

where $S O C_{0}$ is the battery SOCat the initial point; $t_{0}$ and $t$ are the time of the initial point and the time of interest, respectively(h); $\mathrm{C}_{\text {bat }}$ is the battery capacity(Ah); $\mathrm{I}_{\text {bat }}$ is the battery current(A). Equation (24) represents the calculation of battery SOC for ideal batteries. But practically, losses occur during battery charging, discharging and also during storing.
Taking these factors into account, the battery SOC can be expressed by[16]

$$
S O C=S O C_{0}\left[1-\frac{\sigma}{24}\left(t-t_{o}\right)\right]+\int_{t_{0}}^{t}\left(\frac{I_{b a t} \eta_{b a t}}{C_{b a t}}\right) d \tau
$$

Where $\sigma$ is the self-discharge rate which depends on the accumulated charge and the battery health [16], where a proposed value of $0.2 \%$ /day is recommended; $\eta_{\text {bat }}$ is the battery charging and discharging efficiency. For the charging process, in order to reflect the fact that only a fraction of the input energy is really stored, an average approximation of $90 \%$ is used for the charging efficiency while for the discharging stage, a 100\% discharging efficiency is recommended. Like in all chemical processes, the battery capacity $\mathrm{C}_{\text {bat }}$ is temperature dependent. It decreases with decreasing battery temperature at a rate of $0.5-$ $1 \% /{ }^{\circ} \mathrm{C}$, caused by the temperature dependence of the kinetic parameters [17]. Normally, the battery capacity changes can be expressed by using the temperature coefficient $\delta_{c}$.

$C_{b a t}=C_{b a t}\left(1+\delta_{c}\left(T_{b a t}-298.15\right)\right)$

where $C_{\text {bat }}$ is the available or practical capacity of the battery when the battery temperature is $\mathrm{T}_{\text {bat }}(\mathrm{Ah})$; $\mathrm{C}_{\text {batis }}$ the nominal or rated capacity of the battery, which is the value of the capacity given by the manufacturer as the standard value that characterizes this battery. Usually it is specified at nominal operating conditions, a temperature coefficient of $0.6 \% /{ }^{\circ} \mathrm{C}(\delta c=0.006)$ is usually used unless otherwise specified by the data sheet.

In a hybrid solar-wind system, the energy sources are the PV module and the wind turbine and they work together with the battery to meet the load demand. If the cable losses in the system are neglected, the battery current $\mathrm{I}_{\text {bat }}$ can simply be described by

$I_{b a t}=\frac{P_{\text {solar }}+P_{\text {wind }} \eta_{\text {rectifer }}-P_{\text {load }} / \eta_{\text {inverter }}}{V_{\text {bat }}}$

where $\mathrm{P}_{\text {Solar, }} \mathrm{P}_{\text {Wind, }}$ and $\mathrm{P}_{\text {Load }}$ are the power generated by the PV wind hybrid system and the power used in the load respectively. $V_{\text {bat }}$ is the battery voltage. A rectifier is used to convert $\mathrm{AC}$ power from the wind turbine to DC power of constant voltage, and the rectifier efficiency $\eta_{\text {rectifier }}$ is considered to be constant at $95 \%$, in this analysis. The inverter efficiency $\eta_{\text {inverter }}$ is considered as $92 \%$ according to the 
load profile of the system and the specifications of the inverter [18].

\subsection{Experimental Description}

Automobile lead-acid batteries are commonly used for rural renewable energy applications with a capacity of 70 to $100 \mathrm{Ah}$ rated at a $10 \mathrm{~h}$ discharge time. To get the battery voltage response under different battery currents, the following procedure was adopted.

Firstly, the battery was charged with a constant charging current $\mathrm{I}_{\text {charge }}$ to the overcharge-protection voltage (as recommended by the manufacturer and battery testing standards), and then held at this voltage for 20h. According to the testing standards, the battery can be considered as fully charged because the battery voltage did not change during this period of time.

Secondly, the battery was discharged at a constant discharging current $\mathrm{I}_{\text {discharge }}$ until the battery voltage dropped to the deep-discharge protection point $(10.5 \mathrm{~V}$ as recommended by the customer manual and battery testing standard). These two steps constituted a testing cycle. Then the discharge current rate was varied and the procedure repeated for other cycles.

During the entire experiment (five cycles), the battery voltage variations were recorded at 30 minute intervals. The battery voltage variations measured under charging and discharging currents with no interference of external load (charging period) or power supply (discharging period) are shown in Figure 20.

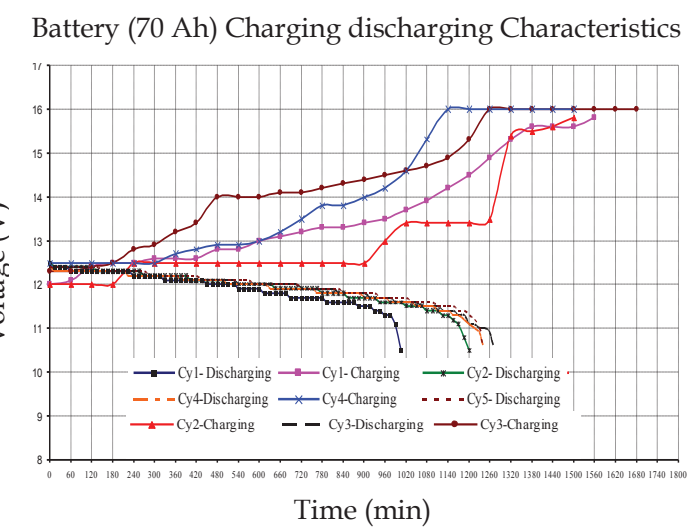

Figure 20 - Lead - acid battery (70Ah) Charging \& Discharging Characteristics
Parameters change due to charging \& Discharging of Battery (70 Ah)

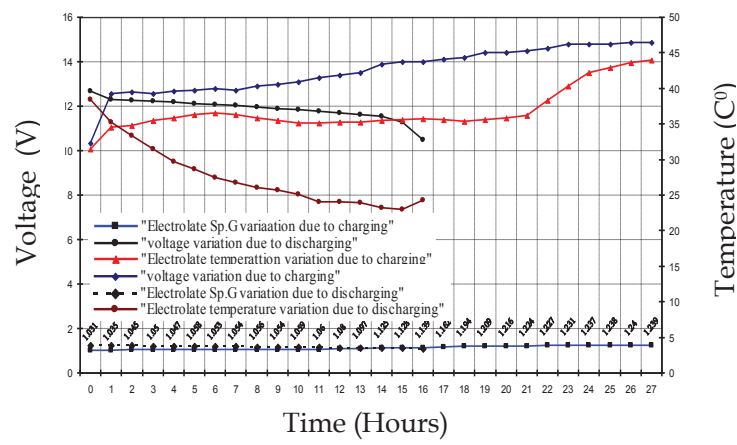

Figure 21 - Variation of Battery Electrolyte Parameters due to Charging and Discharging

Figure 20 describes the battery charging test results. The battery voltages are found to increase dramatically to $15.8 \mathrm{~V} \sim 16 \mathrm{~V}$ during the charging process. Thereafter the battery gets into the overcharge condition, which implies that the battery is almost full and that it will begin to decrease the charge acceptance. As a result, the battery voltage will climb up quickly until it reaches the saturation area where the battery voltage is maximum and the battery cannot accept any more energy. Thus, it can be observed that the lead-acid battery operates within a narrow voltage margin under charging conditions.

A similar situation occurs during the discharging tests as shown in Figure20. The battery voltages are found to be decreasing rapidly to provide a steady electrical discharge until it reaches the over-discharge zone, where the battery voltage will decrease quickly owing to the nonlinear effects of electrochemical reactions in the battery. The battery electrolyte temperature and specific gravity variation were plotted as shown in Figure 21.

\subsection{Battery Efficiency Analysis}

Most storage systems are not ideal. Losses occur in charging and discharging cycles and also during storing periods [16]. The total energy efficiency, $\xi_{\text {bat, }}$ of the battery is expressed as the ratio between the output energy from the battery, $\mathrm{E}_{\text {out }}(\mathrm{kWh} / \mathrm{yr})$, and the total inputs, $\mathrm{E}_{\mathrm{in}}(\mathrm{kWh} / \mathrm{yr})$ :

$$
\xi=\frac{E_{\text {out }}}{E_{\text {in }}} \times 100 \%
$$




\section{Wind and Solar Potential Case Study}

A case study was carried out at a place called Nikavaratiya in the Kurunagala district, Sri Lanka. Four units of $100 \mathrm{~W}$ wind turbines have been installed in Nikavaratiya area as wind home systems and these four locations had been identified as having the best wind speeds. However after commissioning the wind turbines, the generated power was found to be insufficient in fulfilling the electricity requirements of the houses. As a part of this study, the energy requirement for a rural house was estimated by a survey and the net electricity requirement was found to be around 382Wh/day.

The wind and solar data for the selected site measured and recorded at a meteorological station at Nikawaratiya were used in this study. The wind velocity $\mathrm{V}$ and solar radiation G as measured throughout the year 2008 at this station are shown in Figure 22 and Figure 23. The simulation of the dynamic system and its optimization have been done based on these results.

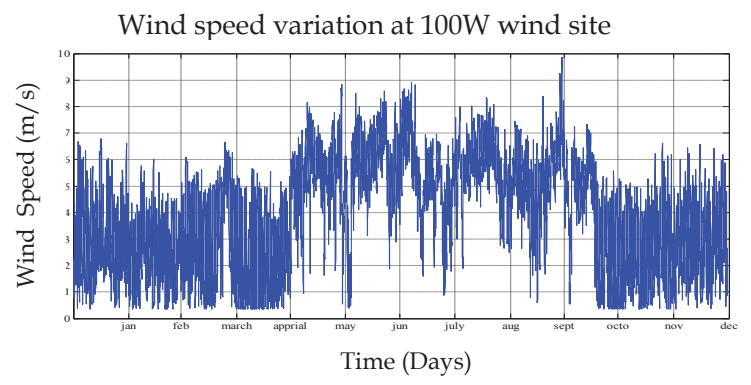

Figure 22 - Annual Wind Speed Variation in the year 2008 at Nikawaratiya , Sri Lanka

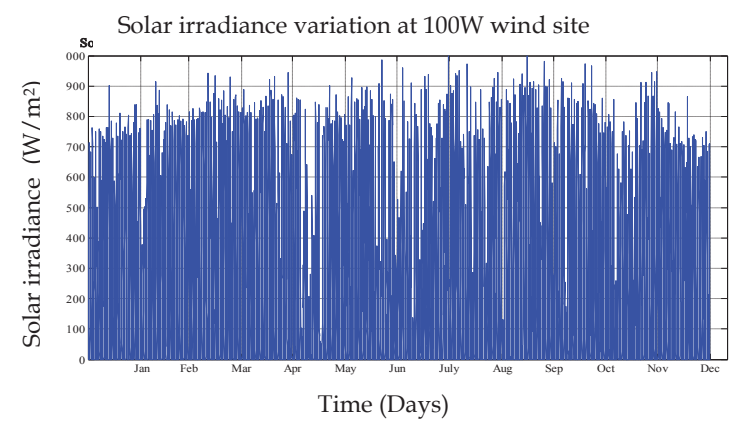

Figure 23 - Annual Solar Irradiance Variation in the year 2008 at Nikawaratiya, Sri Lanka

\section{System Optimization}

In order to efficiently and economically utilize the renewable energy resources, the optimization of the equipment capacities becomes vital. This can assure lowest investment with the full use of the PV array, wind turbine and battery bank, so that the hybrid system can work at optimum level in terms of investment and system reliability requirements $[19,20]$.

\subsection{Simulation and Optimization Software}

The Hybrid Optimization Model for Electric Renewables (HOMER), public domain software produced by National Renewable Energy Laboratory, uses hourly simulations for arriving at the optimum target. It is a timestep simulator using hourly load and environmental data inputs for renewable energy system assessment. It facilitates the optimization of renewable energy systems based on Net Present Cost for a given set of constraints and sensitivity variables [21].

Simulated HOMER hybrid power generation system is shown in Figure 24.

HOMER - [Copy of Nikawartiya hibri wind st

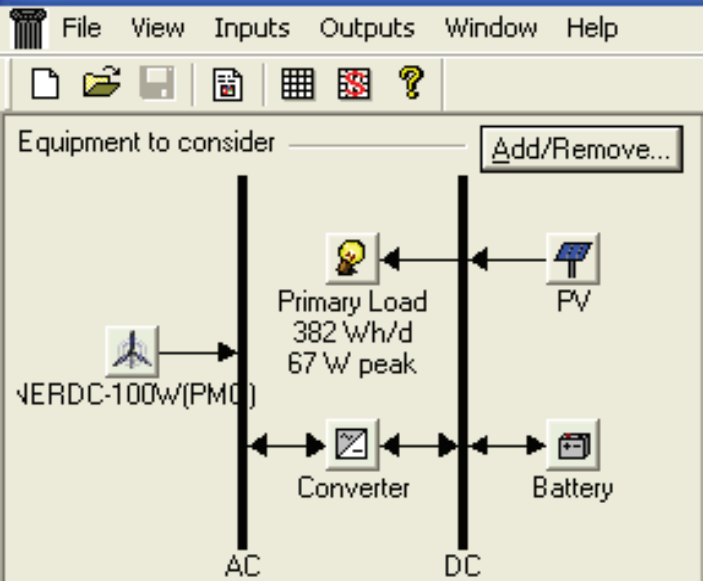

Figure 24 - HOMER Hybrid Architecture for the Optimization of the Size of the Plant

\section{Simulations and Results}

A small wind turbine $(100 \mathrm{~W})$ produced at the National Engineering Research \& Development Centre (NERDC) was simulated in MATLAB/SIMULINK using measured wind speed data in a turbulent wind condition at Nikawaratiya off-grid wind power generation site. Wind turbine's specifications are given in Table 3. 
Table 3 - NERDC 100W Wind Generator

\begin{tabular}{|l|l|}
\hline Generator type & Permanent magnet \\
\hline Rated power & $100 \mathrm{~W}$ \\
\hline Nominal voltage & $16 \mathrm{VDC}$ \\
\hline Number of phases & 3 \\
\hline Number of poles & 8 \\
\hline Method of excitation & Permanent magnet \\
\hline Rating & Continuous \\
\hline Rated maximum current & $5.5 \mathrm{~A} \mathrm{DC}$ \\
\hline $\begin{array}{l}\text { Maximum operating } \\
\text { speed }\end{array}$ & $800 \mathrm{rpm}$ \\
\hline Rated wind speed & $7 \mathrm{~m} / \mathrm{s}$ \\
\hline Cut-in wind speed & $3 \mathrm{~m} / \mathrm{s}$ \\
\hline Cutoff wind speed & $12 \mathrm{~m} / \mathrm{s}$ \\
\hline Rotor & Two blade \\
\hline Rotor diameter & $2.21 \mathrm{~m}$ \\
\hline Rotor profile & NACA 4415 \\
\hline Hub diameter & $0.21 \mathrm{~m}$ \\
\hline & \\
\hline
\end{tabular}

The performance of the system with the MATLAB Fuzzy Logic controller developed and the existing wind turbine with a fixed voltage system were compared. The simulated results show that the system with the Fuzzy Logic Controller performs better than that with the fixed voltage system as shown in Figure 25. With the given wind speed data, energy output over a 1000s period was 2793.5J with a fuzzy controller and 18881.3J with a fixed voltage controller. That is, $47 \%$ more energy can be generated by the system with a fuzzy controller.

Simulation of 100W Wind Turbine with Fuzzy Logic Controller

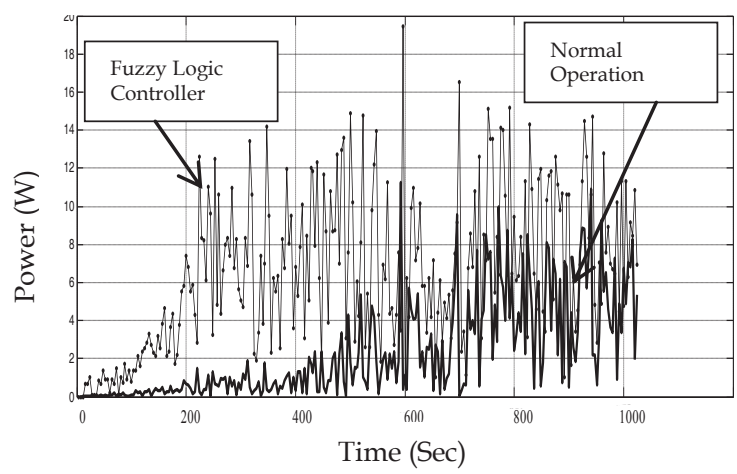

Figure 25 - Simulation characteristics of $100 \mathrm{~W}$ wind turbine with Fuzzy controller

The $\mathrm{P} \& \mathrm{O}$ algorithm was tested with actual irradiance data. Simulations used two sets of data as shown in Figure 26 and Figure 27. The first set of data is the measurements done on a sunny day and the second set of data is the measurements done at the same location on a cloudy day. The data contains irradiance measurements taken every two minutes for a period of 12 hours.
Irradiance values between two data points are estimated by the cubic interpolation in MATLAB functions.

Sunny day irradiance level plot

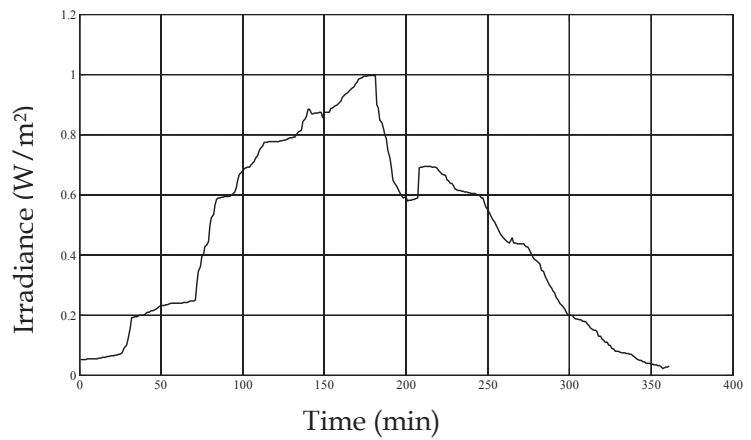

Figure 26 - Sunny day irradiance variation on September $15^{\text {th }}, 2008$

Cloudy day irradiance level plot

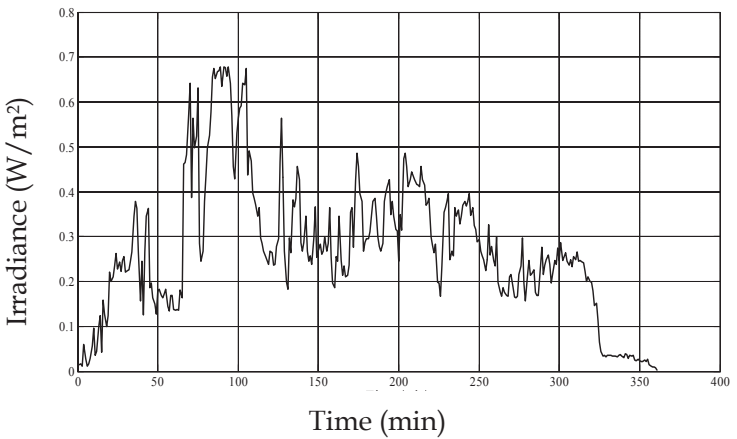

Figure 27 - Cloudy day irradiance variation on October $4^{\text {th }}, 2008$

On a sunny day, the irradiance level changes gradually since there is no influence by clouds. MPP tracking is found to be relatively easy. As shown in Figure 28, algorithms locate and maintain the PV operating point very close to the MPPs without much difference in their performance.

Trace MPP Tracking on a sunny day at $25^{\circ} \mathrm{C}$ (P \&O Algorithm)

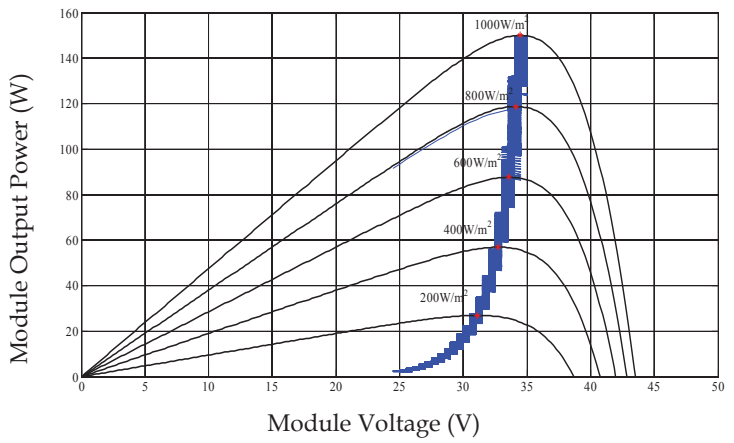

Figure 28 - Trace of MPP tracking on a sunny day $\left(25^{\circ} \mathrm{C}\right)$

On a cloudy day, the irradiance level changes rapidly because of passing clouds and MPP tracking becomes a challenging task. Figure 29 
shows the trace of the PV operating points for the $\mathrm{P} \& \mathrm{O}$ algorithm and the deviations of operating points from the MPPs are obvious when compared to the results of a sunny day.

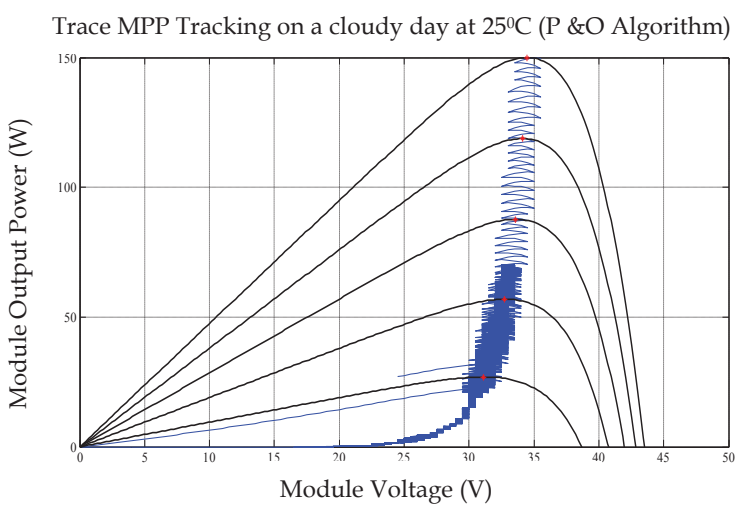

Figure 29 - Trace of MPP tracking on a cloudy day $\left(25^{\circ} \mathrm{C}\right)$

Based on a variety of design parameters such as PV panel capacity and wind turbine capacity, storage lead - acid battery capacity was estimated. For the year 2008, annual average wind speed of $3.92 \mathrm{~m} / \mathrm{s}$ and annual average solar insolation of $5.44 \mathrm{kWh} / \mathrm{m}^{2} /$ day as measured at the $100 \mathrm{~W}$ wind turbine site were used for the simulation study.

The electricity requirement of an average rural household in Sri Lanka was taken as $0.382 \mathrm{kWh} /$ day. Figure 30 shows the monthly average electricity production of the wind and PV hybrid system [22].

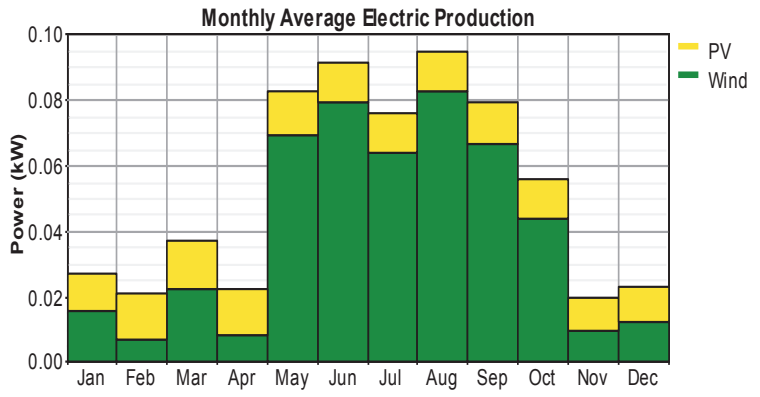

Figure 30 - Monthly average electricity production of the wind PV hybrid system

The $100 \mathrm{~W}$ wind turbine is already available and therefore the wind turbine capacity was set as a constraint in the optimization process. With the above data and constraints, the HOMER optimisation process resulted in a $60 \mathrm{~W}$ photovoltaic panel with one 70Ah Lead acid battery as the optimum for the supply of $0.382 \mathrm{kWh} /$ day, the electricity requirement of a rural home.
Table 4 shows the HOMER optimized solution for the wind solar hybrid system.

Table 4 - HOMER optimized solution for the Wind Solar Hybrid System.

\begin{tabular}{|l|l|l|l|l|l|}
\hline Component & $\begin{array}{l}\text { Size } \\
\text { (W) }\end{array}$ & $\begin{array}{l}\text { Average } \\
\text { output }\end{array}$ & $\begin{array}{l}\text { Max. } \\
\text { Output }\end{array}$ & $\begin{array}{l}\text { Capacity } \\
\text { factor }\end{array}$ & $\begin{array}{l}\text { Hours of } \\
\text { operation }\end{array}$ \\
\hline PV Array & 60 & $\begin{array}{l}0.296 \\
\mathrm{kWh} / \mathrm{d}\end{array}$ & $\begin{array}{l}0.0975 \\
\mathrm{~kW}\end{array}$ & $20.5 \%$ & $\begin{array}{l}4,610 \\
\mathrm{hr} / \mathrm{yr}\end{array}$ \\
\hline $\begin{array}{l}\text { Wind } \\
\text { Turbine }\end{array}$ & 100 & $\begin{array}{l}0.0405 \\
\mathrm{kWh} / \mathrm{d}\end{array}$ & $\begin{array}{l}0.110 \\
\mathrm{~kW}\end{array}$ & $36.9 \%$ & $\begin{array}{l}5,763 \\
\mathrm{hr} / \mathrm{yr}\end{array}$ \\
\hline
\end{tabular}

The primary energy demand on the hybrid system was $0.382 \mathrm{kWh} /$ day. According to Figure 31, four numbers of 70Ah batteries are required for feeding this amount of energy to the system. As shown in Figure 32, battery SOC level is close to the $100 \%$ region, minimizing the fluctuation of the battery charging level.

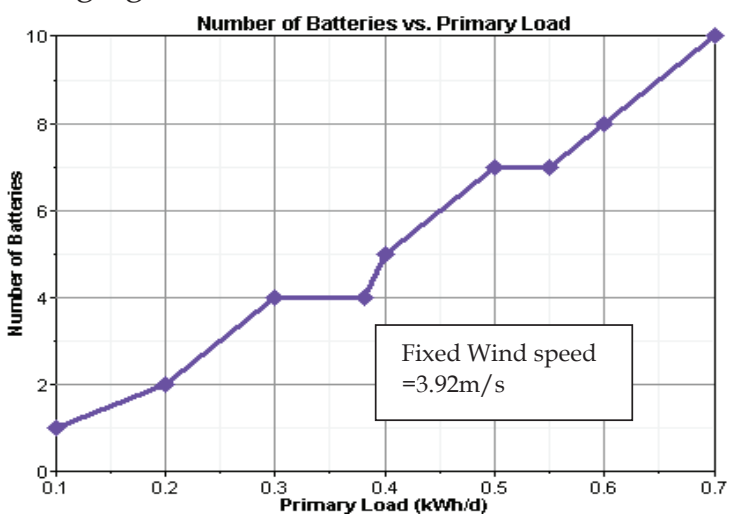

Figure 31 - Number of Batteries Vs Primary load Characteristics plot

With one 70Ah battery, the SOC level fluctuates rapidly. The main reason for this fluctuation is the low generation by the wind turbine and the PV panel due to weather pattern distribution during the year. The best battery SOC behaviour close to $100 \%$ is shown during six months of the year (May to October) and during this period excess energy is generated. To absorb this excess energy generated, a hybrid system was added with four 70Ah batteries.

Battery state of charge (\%) of Wing Solar Hybrid System

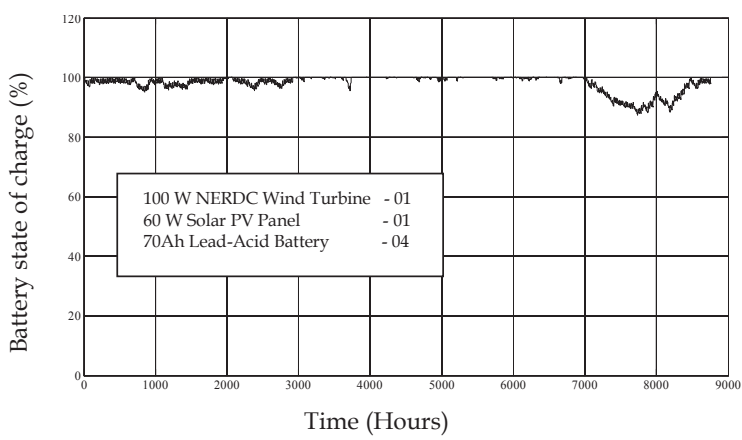

Figure 32 - Battery State of Charge (\%) of a Hybrid system (Four Battery) 


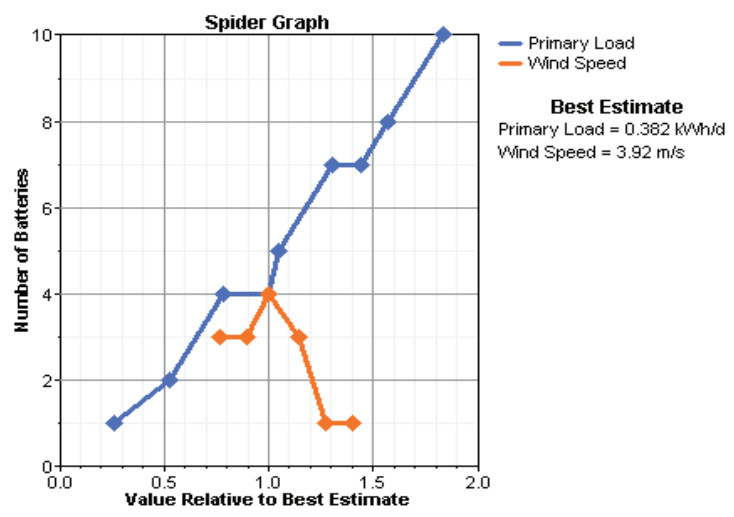

Figure 33 - Relative best estimation results of the hybrid system.

Figure 33 shows the relative best estimation result with the number of batteries used in the hybrid system operating at $0.382 \mathrm{kWh} /$ day at $3.92 \mathrm{~m} / \mathrm{s}$ wind speed. A hybrid system with four batteries can be utilized as shown in Figure 33 to get the optimal solution for energy absorption from the system and maintain the SOC level at close to 100 percent. According to the analysis, the optimum renewable energy system that can fulfil the energy demand of a typical rural home consuming $400 \mathrm{Wh} /$ day is as shown in Table 5.

Table 5 - Optimal Renewable Energy Requirement for Generate $400 \mathrm{Wh} /$ day

\begin{tabular}{|l|l|}
\hline Average Wind Speed & Optimum system \\
\hline$<3.5 \mathrm{~m} / \mathrm{s}$ & Solar Home System \\
\hline $3.5 \mathrm{~m} / \mathrm{s}-4.5 \mathrm{~m} / \mathrm{s}$ & $\begin{array}{l}100 \mathrm{~W} \text { Wind turbine } \\
\text { with Solar Hybrid } \\
\text { system }\end{array}$ \\
\hline$>4.5 \mathrm{~m} / \mathrm{s}$ & $100 \mathrm{~W}$ Wind turbine \\
\hline
\end{tabular}

\section{Discussion \& Conclusion}

Techniques that employ wind sensors are relatively expensive, but they perform well with wind speed variations, particularly when the control system responds quickly to variations in wind conditions. However, in practice it is difficult to accurately measure wind speed by an anemometer installed close to the wind turbine, because the wind turbine experiences different forces due to wake rotation.

Therefore, it is useful to have a sensor less control strategy for small wind turbine systems which operate without predetermined turbine characteristics.
"Perturbation \& observation searching method" operates without knowing the system parameters. However, it is difficult to acquire optimum operating points from outputs of the wind turbine, as mechanically stored energy is interlaced with the aerodynamic power of the wind rotor.

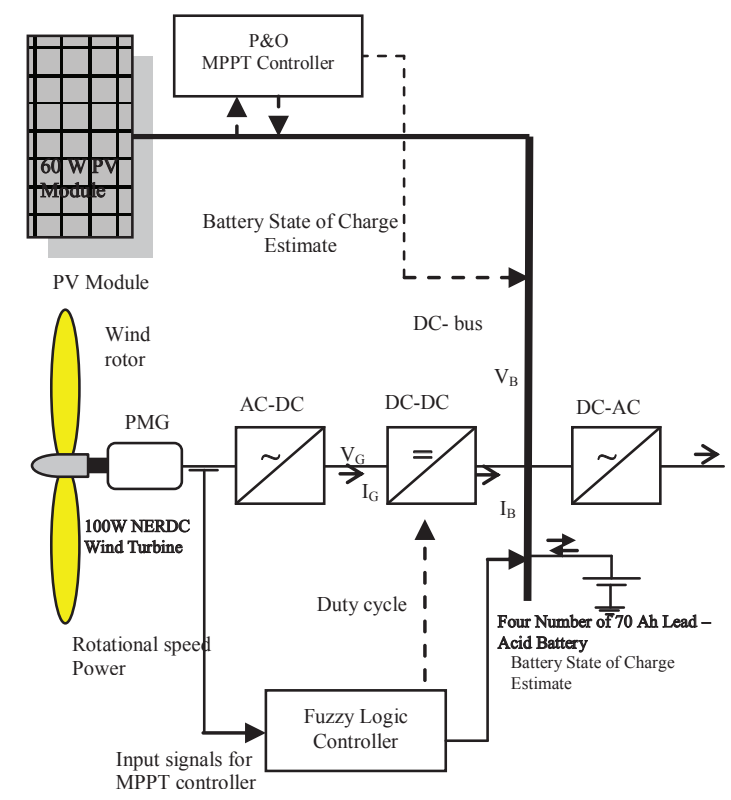

Figure 34 - Optimal Power Generation Hybrid Architecture for Nikavaratiya 100W Wind Turbine Generation Site

In this paper, a fuzzy logic based MPPT control system is introduced for small wind turbines. Fuzzy sets and fuzzy rules were developed by considering qualitative quantities of wind turbine outputs to track optimum operating points of the system. The MPPT algorithm is simulated in MATHLAB platform. The simulation result shows the efficiency of $96.2 \%$ for the P \& O algorithm. Figure 34 shows the pilot wind solar hybrid pilot system developed and used in this study.

The research outcome shows that the proposed fuzzy controller performs better than a conventional controller and $47 \%$ more energy can be generated by the system with a Fuzzy controller.

\section{References}

[1] Ellition, D., Schwartz, M., Scott, G., Haymes, S., Heimiller, D., George, R., Wind Energy Resource Atlas of Sri Lanka and the Maldives, National Renewable Energy Laboratory USA.

[2] Ackermann Thomas, Wind power in power system. John Wiley \& Sons Press; 2005.

[3] Narayana, M., Putrus, G., Jovanovic, M., Leune, P., Maximum Power Tracking for 
Variable Speed Fixed Pitch Small Wind Turbines. Prague, 8-11 June 2009, pp 542.

[4] D Le. Gourieres, 1982, Wind Power Plants Theory and Design, Oxford: Pergamon press, pp76-120.

[5] Chan, T. F., Lai, L. L., An Axial-Flux Permanent-Magnet Synchronous Energy for a Direct-Coupled Wind Turbine System. IEEE Trans Energy Convers 2007; 22(1).

[6] Bansal, R. C., 2003. Bibliography on the Fuzzy set Theory applications in Power Systems (1994 - 2001)", IEEE Trans. Energy Conversion , 18, pp 1291 - 1299.

[7] Cox, E., Fuzzy Fundamentals, IEEE Spectrum, vol. 29, October 1992. pp. 58-61.

[8] Simoes, M. G., Bose, B. K., Spiegel, R. J., Fuzzy Logic Based Intelligent Control of a Variable Speed Cage Machine Wind Generation System. IEEE Trans Power Electron 1997;12(1), pp 87-95.

[9] Copetti, J. B., Chenlo, F., Lorenzo, E., A General Battery Model for PV System Simulation.1993;1, pp 283-292.

[10] Hohm, D. P., Ropp, M. E., “Comparative Study of Maximum Power Point Tracking Algorithms" Progress

Photovoltaics: Research and November 2002, pp 47-62.

[11] BP Solar, BP SX150 - 150W MultiCrystalline Photovoltaic Module Datasheet, 2010.

[12] Castañer Luis \& Santiago Silvestre Modelling Photovoltaic Systems, John Wiley \& Sons Ltd, 2002.

[13] Hussein, K. H., Muta, I., Hoshino, T., Osakada, M., "Maximum Photovoltaic Power Tracking: An Algorithm for Rapidly Changing Atmospheric Conditions" IEE Proceedings - Generation, Transmission and Distribution - v. 142 January 1995, pp 59-64.

[14] Lee Dong-Yun, Noh Hyeong-Ju, Hyun DongSeok, Choy Ick, An Improved MPPT Converter using Current Compensation Method for Small Scaled PV- applications. In: IEEE Conference, vol. 3; 2003, pp 540-45.

[15] Catherino, H. A., Burgel, J. F. et al. Modelling and Simulation of Lead -Acid Battery Charging. J Power Sources 2001;96(1), pp113 - 120.

[16] Jossen, A., Garche, J., Sauer, D.U., 2004. Operation Conditions of Batteries in PV Applications, pp m759-769.

[17] Kim, S. C., Hong, W.H., 1999. Analysis of the Discharge Performance of a Loaded Lead/Acid Cell using Mathematical Modelling. J. Power Sources 77, pp 74-82.

[18] Salameh, Z. M., Cassacca, M. A., Lynch, W.A., A Mathematical Model for Lead-Acid Batteries. IEEE Trans Energy 1992;7(1), pp 93-7.

[19] Borowy, B. S., Salameh, Z. M., Methodology for Optimally Sizing the Combination of a Battery Bank and PV Array in a Wind/PV
Hybrid System. IEEE Trans Energy Converse 1996;11(2), pp 367-373.

[20] Ekren, O., Ekren, B. Y., Ozerdem B., BreakEven Analysis and Size Optimization of a PV/Wind Hybrid Energy Conversion.

[21] Kellogg, W. D., et al. Generation unit Sizing and Cost Analysis for Standalone Wind, Photovoltaic and Hybrid Wind/PV systems. IEEE Trans Energy Converse 1998;13(1): pp 70-5.

[22] Yang, H. X., Lu, L., Zho, W., A Novel Optimization Sizing Model for Hybrid Solar - Wind Power Generation System. Solar energy 2007;81(1), pp 76-84 